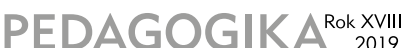 \\ N.3 (73) SPOŁECZNA
}

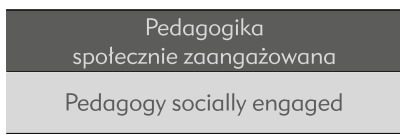

Maria Mendel

University of Gdańsk

ORCID: 0000-0002-4022-502

DOI: https:doi.org/10.35464/1642-672X.PS.2019.3.04

\section{Radically engaged social pedagogy On the currency of the work of Teodora and Izydor Gulgowski}

to Tadeusz Pilch

A B S T R A C T: Referring to the permanent features of social pedagogy, which are interested in interventions in social relations that fill the public space, the text - in the light of the contemporary equality crisis (along with growing nationalist tendencies, xenophobia development) - presents arguments about the relevance of social pedagogy in a radically engaged trend. The ground for this is found in the Movement of Socially Engaged Pedagogues and the initiating thought of Tadeusz Pilch and the reflection and social-educational practice of Izydor and Teodora Gulgowski, activists who a hundred years ago were reviving folk craftsmanship and spirit at the same time, dealing well with national and local community confrontations at Kashubia. This is an example of social animation, which through the solutions analysed in the text may indicate contemporary inspiring and strengthening representations of the trend of radical engagement in social pedagogy.

K E Y W O R D S: Social pedagogy, radical involvement, equality crisis, nationalism, locality.

\section{Introduction}

This statement was supposed to be a reference to the idea that social pedagogy in international circulation is public pedagogy (Biesta 2012; Giroux 2015; Skrzypczak 2016; Mendel 2017; other). Social pedagogy with Polish 
roots is clearly a "pedagogy of public", actively entering the space of social and political relations (interrupting them and influencing their change) in an educational way, sensitive to the nuances of contexts and differences, and hence always subtle in its intentionality, striving for their subjective varieties, grounded in the values of the common good, equality, social justice and democracy (Radlińska 1935; Lepalczyk, Pilch 1995; Marynowicz-Hetka 2006; 2012; Pilch 2008; Theiss 2018a, other). Therefore, my reference turned out to be a trip to the thoughts and activities of Tadeusz Pilch, who represents this pedagogy and to whom I dedicate this text with admiration. The achievements of Tadeusz Pilch are directly in line with the standpoint that "social pedagogy is in close relationship with politics, understood not as political power (politics), but as educational, civic filling of public and social space (polis). It is a space for social pedagogy research and activities (Smolińska-Theiss 2018, p. 12).

The direct cause of this text, however, was certain event ${ }^{1}$. As a consultant in one of the local projects, I had the opportunity to do a small, albeit important, research revisit concerning the material left by Teodora and Izydor Gulgowski, a village teacher and his wife, who in the first decades of the 20th century created something in Kashubia that still today appears to be a wonderful work and - with all the difficulty of synthetically expressing its essence - in the community of social pedagogues could be called a unique settlement. While getting to know this material, I was constantly intersecting two perspectives: the past of the century ago and the contemporary reality; the positivist struggle of the teacher against poverty of the people, successfully conducted as a committed ethnography of folk culture, and social pedagogy today, also committed, but as if powerless, hardly audible in the contemporary cacophony of crises and therefore recently "awakened" to a stronger participation in overcoming them, etc. Against this background there are the characters of committed pedagogues - then, now... What can be seen in these intersections?

One of the most important common points is a similar understanding of upbringing. It is an upbringing whose meaning is seen in close connection with the environment and the participating, active influence on it. It is about a committed "upbringing-in-environment". Regardless of our different cultural epochs, both the Gulgowskis and the today's social pedagogues try to bear witness to this by their activities. Their pedagogical ontologies can also be

\footnotetext{
The association of this event with the earlier plan of the content of this text is due to the impulse I received from Wiesław Theiss - thank you very much!
} 
easily combined, seeing how they share the need for pedagogical building on diagnosis, always carried out as involved getting into the environment without evading challenges [as Helena Radlińska would put it (1935, p. 75-76, other)]. In the case of Tadeusz Pilch and the Gulgowskis, village turned out to be an integrating environment for them: Pilch 2019). It was village that polarised thoughts and directed actions, both scientific and socio-educational, as well as political. The formula of intentionality is also common in both of them it is the upbringing "towards" an ideal, clearly "towards" a better functioning community, a high quality of life for all, etc. ${ }^{2}$. Therefore, we are talking about functional, even instrumental upbringing, but with the characteristic feature that it is undertaken in a ruthless service of helping others. What is extremely important, the assistance refers to solidarity and is strongly rooted in it (it reveals an attitude - contrasted with charity - of solidarity-based division of the world). Continuing in this context, both cases are also connected by a focus on changing the subject in the sphere of causality, in the physical space of action; they are linked by a pedagogical concept of work towards a change in the environment using the forces of the environment, in the service of an ideal... I am writing about it in Radlińska's language, because these multiplying points of commonality could be placed under the banner of social pedagogy, realized in a variety engaged in a radical sense, that is drawing from this great activist and politician who with great energy joined the discourses creating new education and a better world of the 20th century... As I recently pointed out ${ }^{3}$, Wiesław Theiss, inscribing his words in the jubilee of the 100th anniversary of Poland's regaining independence, reminded Helena Radlińska’s harsh criticism

2 As for Tadeusz Pilch, who was born and raised in Bielcza, Little Poland region, village is a small homeland (see: Pilch 2019) and for years has been not only his centre of research interest, but also his concern as a citizen and politician sensitive to the situation of rural areas (he is an animator of the movement of People's Universities, initiator and first president of the Society of People's Universities in Poland, activist of the Polish People's Party, deputy minister of education in 1992-1995). He was involved in researching schools in this environment, teachers, rural youth and children, their developmental and educational opportunities and quality of life in conditions of difficult access to diverse forms and educational institutions (see e.g. 1977; 2001; Janicka et al. 2013). In turn, with regard to the Gulgowskis, village was their home and place of their beloved work at the same time. They made Wdzydze, Kashubia a place of an important undertaking not only in pedagogical terms, but also socially and politically, creating new forms of life and work for the rural community, as well as a unique museum, a living open-air museum (Gulgowska 1910; Gulgowski 2012 (1911)). They were active in associations for rural areas, also co-creating them as initiators and first founders (I write about it further).

3 I am thinking about my part of the co-authored article: Mendel, Naumiuk, Skrzypczak (2018). 
of nationalistic concepts "under the sign of the National League" (2018b, p. 150). He quoted an opinion on - strongly emphasized also today - position of nationalists on school and education, which, according to Radlińska, "limits the horizons and inhibits the aspirations for change", and their attitude and promotion of the controversial "pedagogy of memory", which reduces national education to "constant looking back at graves", is a "robbery of nationality" (Theiss 2018, p. 150). She wrote: "(in) the name of the Polish school and the rebirth of the nation, the young generation is moving towards the graves and, having lit the lamps there, considering the past, not as free heirs of this past, but as slave debtors. The issue of education does not agree to be a slave of one slogan, one idea that excludes others, even the Polish idea, from the most lofty moments of the past brought up under the responsibility of life, for which it is to prepare employees" (Radlińska 1908, quoted from: Theiss 2018, p. 150).

Feeling the affinity of these thoughts and approaches, I saw in them the ground for the thesis on the currency of social pedagogy in the radically engaged current, and in the social and educational reflection and practice of Izydor and Teodora Gulgowski - today inspiring and strengthening the representation of this current. I try to argue this thesis in this text.

\section{Social pedagogy in a radically engaged version Why now?}

In 2016 Tadeusz Pilch initiated the founding of the "Movement of Socially Engaged Pedagogues", gathering numerous Polish social pedagogues, for good reason (see: Dąbrowska 2016). The first proclamation he formulated to its members was made in the context of the successive manifestations of the nightmare of the refugee crisis. In Poland, it is experienced in bizarre forms when, for example, the Polish government refused to provide Syrian children with assistance organised by local authorities. Not avoiding expressing strong emotions (involvement does not take place only in the intellectual sphere...), he wrote that pedagogues cannot remain indifferent in any way and that in view of the fact that Poland is putting up "humanitarian aid barriers" they must work to overcome them (Pilch 2017). This triggered a discussion ${ }^{4}$, but subsequent texts, later published more regularly as newsletters, are kept in a si-

4 See e.g. the voice of Aleksander Nalaskowski: Wstyd - w odpowiedzi profesorowi Tadeuszowi Pilchowi (Shame - in response to Professor Tadeusz Pilch), http://sliwerski-pedagog. blogspot.com/2016/10/wstyd-w-odpowiedzi-profesorowi.html (access date: 11.06.2019). 
milar spirit. Why does Tadeusz Pilch wake up pedagogues? Why does he do it with so much power and why now?

The answer can be found in the explanations of contemporary crises. One of the most interesting explications refers to the concept of the crisis of equality, which includes many others, since the main source of social problems is inequality. I am thinking of Pierre Rosanvallon's "The Society of Equals", where the author claims that we are experiencing another crisis of equality. The first one was the years of the first globalisation (1880-1900), when it manifested itself "in the growth of nationalism and protectionism with xenophobic attitudes, which led some to propose the principle of identity and homogeneity as a response to the 'social question"' (Rosanvallon 2013, p. 9). This is how the foundations were laid for the deep crisis of equality that we are experiencing today, when, as Rosanvallon writes, "nationalism, protectionism, xenophobia: all these things are with us again" (Rosanvallon 2013, p. 9). "All these things", the elements that make up the contemporary crisis social condition, are taken up in social pedagogy, in response to these conditions which lively formulate social and educational concepts. From my own perspective, I can see that they concern, among other things, the commitment to a permanent presence in the reflection on the "social factor" (Skrzypczak 2016) and caring for the common good in the framework of active co-creation of public space, orientation towards memory and place or place of commonality (Mendel 2017; Mendel, Naumiuk, Skrzypczak 2018; Mendel, Theiss 2019).

In such an understanding of commitment, in such a committed pedagogy one can see a tendency - mentioned after Radlińska - to "get into" the world as a not indifferent object of analyses ${ }^{5}$ for a researcher. It is therefore about creating knowledge as an achievement of understanding, which determines pedagogical action, and is an immersion in the world that is the space of this action. Close to the epistemological canons of anthropologists. As Feyerabend wrote, "tribal society, if an anthropologist is to understand it, should be present in him/herself and not only in his notes" (Feyerabend 1995, p. 137). An involved pedagogue, like Tadeusz Pilch in his proclamations, speaks from outside his own notes. In Pilch's case, his voice is formed by many

5 She wrote: "While learning about an environment, one cannot save time to get into it, to get to know not only the external conditions of its existence, but also the concepts and desires living in it, the essence of its spiritual power and the bonds that connect it with the wider world. Personal careful watching and listening cannot be replaced by the most ingenious questionnaires" (Radlińska 1935, s. 75). 
years of "getting into" the world of profound inequalities (see, among others, Pilch 1977, 2001; Janicka et al. 2013). The adequacy ${ }^{6}$, significance and power of this voice, as we feel now, can be linked to the current crisis of equality described by Rosanvallon, which, both in Poland and in many other countries, raises nationalism to the highest rank, and makes xenophobia a value (see e.g. Mendel, Naumiuk, Skrzypczak 2018). In these circumstances and in the face of these challenges, social pedagogy radicalises its involvement. In this way, the educational tools it uses gain a chance of effectiveness in the world that instrumentalises its ideals - public welfare, community, etc.

And one more element of that argumentation. Due to the ontological status of understanding, it is inseparably accompanied by the discourse of truth. From this perspective, we can see that there is a kind of a Foucault "theoretical practice" in the involvement of pedagogues today (Foucault 2011, other). It can be a strategic concept of theory, manifested in the form of a "policy of truth" (Lemke 2009, p. 48). A necessary condition is the reflection on the conditions (social, cultural, historical, etc.) that make a certain - socially, culturally, historically shaped knowledge "true" and generate theoretical and extratheoretical consequences of these "truths" (Lemke 2009, p. 48). The theory of social pedagogy in a committed version - e.g. the mentioned concepts (social factor, common place or memorial place, etc.) - seems to meet this condition when created in conditions of immersion in socio-political reality. Regardless of political tides, such as election results that reformulate entire truth markets, it offers a theoretical practice capable of effectively pursuing the policy of truth. Consequently, regardless of the emotions involved in its message, this practice is, on the one hand, maintaining a permanent distance from quasitrue narratives, including those that are politically useful. On the other hand, this socio-political work of committed pedagogy theory is confronted with socially dangerous ideologies (such as radicalising nationalism nowadays) and a consistent pursuit of social and educational ideals, in particular cultivation of the solidarity that has grown out of concern for all those who, in a success logic-laden world after neoliberalism, have turned out to be forgotten or invisible. In this context, the work of Izydor and Teodora Gulgowski appears to be fruitful and inspiring.

6 Apart from the fact that the Movement of Socially Engaged Pedagogues brings together dozens of people, Tadeusz Pilch's proclamations arouse controversy among others. See e.g. Dąbrowska 2016. 


\section{The Gulgowskis - "sincere democrats" in action}

Recalling Rosanvallon again, it is easy to see that the activities of Teodora and Izydor Gulgowski coincided with the years immediately after the "first globalisation (1880-1900)" in which the crisis of equality manifested itself as growing nationalism and xenophobic attitudes (Rosanvallon 2013, p. 9). It was against them that the initiatives of this committed marriage were directed when, for example, they joined the association under the name Verein für kaschubische Volkskunde, founded in 1907 and based in Kartuzy. Izydor edited its journal and was the secretary of the association, which according to its statute was "strictly scientific and apolitical in nature". It gathered both Poles and Germans who wanted to work for the heritage of the Kashubian culture (Borzyszkowski 2012, p. XXXI).

As such, however, it had problems - on the one hand, with attacks from German nationalists who demanded a nationally polarised option (Borzyszkowski 2012, p. XXXI). On the other hand, activists fighting for the Polishness of Kashubia, such as the famous writer and local doctor Aleksander Majkowski, also saw a threat to the universality of the idea of an association located beyond national divisions. In response, Majkowski, around whom the young Kashubian and Pomeranian intelligentsia gathered, established the monthly "Gryf. Pisma dla spraw kaszubskich" in 1908. The "Gryf" environment became the leaven of the Young Kashubian movement, formed directly in reaction to the activity of the Verein für kaschubische Volkskunde. The resulting paradox was that "its (Verein...) apoliticism and sympathy towards the Kashubians and the Kashubia region, as A. Majkowski noted, could have accelerated the Germanisation of the Kashubia..." (Borzyszkowski 2012, p. XLI).

How did the Gulgowskis behave in this situation; did they take sides in the emerged confrontation, in the understanding of a manifestation of national affiliation? No! Above all, they worked hard to develop a PLACE that could attract both sides, everyone, regardless of their nationality; and in which they themselves would feel comfortable. It attracted Germans who enjoyed the beauty of cultural diversity (as they thought of Kashubia) in a simply magnetic way, and it also made a very strong impression on young Kashubians, who were enchanted by the handicrafts and other artefacts of local culture gathered there. But it could not have lasted any longer. I would like to remind you, after Rosanvallon, that the first globalisation first caused an increase in nationalistic and xenophobic moods, and then, in the years when 
the Gulgowskis were developing their place, it brought fruit in the form of homogenization - "the principles of identity and homogeneity as a response to the 'social question"', i.e. escalating shortages and poverty $(2013$, p. 9). The "homogeneous" on the German side became more expansive than those on the Polish side. In a situation of growing Germanisation, especially the ruthless one, performed by Hakata ${ }^{7}$, the Gulgowskis emphasized Polishness more strongly and, as Borzyszkowski writes, formed "an extraordinary oasis of Kashubian- and Polishness" (2012, p. XXXVII). What is this place?

Let's start with a few more sentences about its founders. Izydor Gulgowski (1874-1925), son of a rich farmer from Kociewie and a Kashubian mother from the region of Wiele, graduated from a teacher's seminar in Tuchola and began teaching in Kashubia, eventually settling down as a teacher at a school in Wdzydze Kiszewskie (German: Sanddorf, in the Kościerzyna - Berent district) in 1898. In 1899, while living there, he married Teodora nee Fethke, daughter of a German teacher, sister of a parish priest from nearby Wiele and a relative of another priest, Stanisław Sychowski, an "organic worker" popular in Pomerania who ignited the enthusiasm of the people for cottage industry (Borzyszkowski 2012, p. XX). Teodora was called "a Kashubian German" (Borzyszkowski 2012, p. XXXVII). Married after painting and applied arts studies in Berlin, she fell with great love and enthusiasm for the folk culture that surrounded her. Together with her husband, who always found time to share his interests with her outside of work, they spent the whole of their lives studying and researching ethnography, visiting Kashubia, collecting folk art, memorabilia of old customs, etc. They also wrote a lot scientific and popularizing works, among others, in Gdańsk magazines. Izydor's Germanlanguage work from 1911 is now part of the canon readings in cultural studies. This is a comprehensive monograph $O$ nieznanym ludzie $w$ Niemczech. Przyczynek do ludoznawstwa i krajoznawstwa Kaszub ("About unknown people in Germany. Contribution to folk and landscape studies in Kashubia) [Gulgowski 2012 (1911)], which, because of its language and title, became for him - a soldier of the Polish army in 1920 - a cause of numerous troubles (he also published a summary of the book in Polish).

\footnotetext{
It is the Verein zur Förderung des Deutschtums in den Ostmarken, the German Eastern Marches Society. It was a nationalist organisation operating in the years 1894-1934 in the eastern provinces of Germany, working for the benefit of Germanisation. The common name Hakata comes from the first letters of the founders' names: financier Ferdinand von Hansemann and landowners Hermann Kennemann and Heinrich von Tiedemann, often spelled in Polish literature as H-K-T, H.K.T. or simply Hakata (https://pl.wikipedia.org/wiki/Hakata; access date: 20.06.2019).
} 
The Gulgowskis made numerous contacts and made friends with masters in the field they were interested in, such as the researcher of the Kashubian language and folklore, Professor Friedrich Lorentz, or a village teacher, writer, outstanding regionalist and social activist, Professor Heinrich Sohnrey. With Lorentz, Izydor founded the aforementioned association Verein für kaschubische Volkskunde, and Sohnrey, as part of the activities of another association he chaired and in his magazine "Das Land", gave Gulgowski a number of examples of acting for the protection and development of regional culture, which through the dissemination of handicraft, cottage industry, etc., was the same as raising the standard of living of local communities (Borzyszkowski 2012, p. XIX).

Under these conditions, the spouses' involvement in the work to improve the lives of the rural population gradually increased. This work was becoming, of course, more and more advanced. Crafts inspired by them (embroidery, basketry, etc.) flourished in Wdzydze and the surrounding area, giving a profit, especially desirable in winter, when life in the village was fading. Given the poor quality of the soil, capitalist regulations prohibiting Kashubian people the everlasting right to fish for their own needs caused a real threat of hunger in winter (Borzyszkowski 2012, p. XXIII). Therefore, the development of the "home industry", as these works were called in the countryside, progressed quickly.

Teodora began with embroidery, to which she encouraged girls, giving them patterns developed by herself on the basis of her studies ["Once, in winter, during a wedding, a group of young girls gathered around me..."] (Fethke-Gulgowska 1910, p. 144). Reading in the book of her husband O nieznanym ludzie... a fragment of her press article: Jak na to wpadłam, żeby wprowadzić rzemiosło domowe ("How did I come up with introducing home craft?") (Fethke-Gulgowska 1910), I had the impression that the author told me something perfectly well known in social pedagogy. In fact, she even uses words that social pedagogues use very often, e.g. "animating" - of embroidery, craft, village (Fethke-Gulgowska 1910, pp. 143, 146, other).

All this happened initially in the Gulgowskis house, their wooden "Villa Kaszubska" ("Kashubian Villa") with a lounge with a fireplace, a studio of the two ethnologists and at the same time Teodora's painting studio ${ }^{8}$. It spread to a wider area when the spouses, inspired by the first in Europe open-air museum in Stockholm (1891), founded the Rural Museum in Wdzydze in 1906

8 The villa burned down in 1932 during a fire of the whole village. 
(Borzyszkowski 2012, p. XXV). It consisted of a land and a historic cottage from the 18th century, in which the spouses gathered their collection of monuments of ancient folk art, architectural elements and documentation of the objects of old architecture, which they themselves drew up. This undertaking was enthusiastically received by both Polish and German cultural scientists and residents, who immediately treated the open-air museum as their own place, enriched by them, attended and liked.

This is what Józef Borzyszkowski wrote about Izydor Gulgowski: "being a teacher in a Prussian-German school, obliged to promote Germany, and still being a loyal official cooperating with the Germans, he was at the same time conducting pro-Polish activity" (2012, p. XXXVII). This attitude "between" national identities and interests was the result of conscious choices and decisions. It seems that the most important role in them was played by the most valuable and closest thing - the local stuff. The place that Izydor and Teodora created in Kashubia, seems on the one hand to be like the eye of a cyclone, a zone of silence in a raging storm of constantly confronted national identities. On the other hand, it can be described as the materialization of these opposing options met at the crossroads. Anyway, the "oasis" created in Wdzydze by the Gulgowski family does not allow for binary oppositions, makes us think about something third, becoming an expression of some supranational trialectics, rather effectively breaking the nationalistic tendencies.

When Izydor died in 1925 and Teodora in 1951, they were buried in a common grave, on a forest hill belonging to their property, near the $\mathrm{Mu}$ seum they created. In the chronicle of the school where Izydor worked, it was written: "He was a great social and scientific activist. He developed folk industry in Kashubia and published scientific works about Kashubia. At the same time, he was a sincere democrat (emphasis by MM), which made him win the hearts and recognition of the people of Wdzydze, whom he loved sincerely [...]" (Borzyszkowski 2012, p. LXV).

Now that "nationalism, protectionism, xenophobia: all these things are with us again" (Rosanvallon 2013, p. 9), radical involvement of social pedagogy can stand for various forms of following the path of Teodora and Izydor Gulgowski; ontologies of "sincere democracy".

\section{References}

Biesta G.J.J., 2012, Becoming public: public pedagogy, citizenship and the public sphere, "Social \& Cultural Geography", 13, 7, pp. 683-697.

Borzyszkowski J., 2012, O Izydorze Gulgowskim, jego żonie Teodorze z Fethków oraz ich dokonaniach i związach $z$ młodokaszubami, [in:] Gulgowski I., O nieznanym ludzie 
w Niemczech. Przyczynek do ludoznawstwa i krajoznawstwa Kaszub, transl. Magdalena Darska-Łogin, under scientific edition and with introduction by Józef Borzyszkowski, Berlin-Gdańsk: Instytut Kaszubski.

Fethke-Gulgowska T., 1910, Jak na to wpadłam, żeby wprowadzić rzemiosło domowe, [in:] Gulgowski I., O nieznanym ludzie w Niemczech. Przyczynek do ludoznawstwa i krajoznawstwa Kaszub, transl. Magdalena Darska-Łogin, under scientific edition and with introduction by Józef Borzyszkowski, Berlin-Gdańsk: Instytut Kaszubski, pp. 143-154.

Feyerabend P.K., 1995, Przeciw metodzie, "Nowa Krytyka. Czasopismo Filozoficzne", no. 6, pp. $105-178$.

Foucault M., 2011, Narodziny biopolityki, transl. Michał Herer, Wydawnictwo Naukowe PWN, Warszawa.

Giroux H., 2015, Education and the Crisis of Public Values. Challenging the Assault on Teachers, Students, and Public Education, Peter Lang, New York.

Gulgowski I., 2012, O nieznanym ludzie w Niemczech. Przyczynek do ludoznawstwa i krajoznawstwa Kaszub, transl. Magdalena Darska-Łogin, under scientific edition and with introduction by Józef Borzyszkowski, Instytut Kaszubski, Berlin-Gdańsk.

Lemke T., 2009, Foucault, rządomyślność, krytyka, "Recycling Idei”, no. 9, pp. 40-48.

Lepalczyk I., Pilch T. (ed.), 1995, Pedagogika społeczna. Człowiek w zmieniajacym się świecie, Wydawnictwo Akademickie "Żak", Warszawa.

Marynowicz-Hetka E., 2006, Pedagogika społeczna. Podręcznik akademicki, Wydawnictwo Naukowe PWN, Warszawa.

Marynowicz-Hetka E., 2012, Społeczny wymiar działania w polu praktyki socjalnej: istota i sens, "Zoon Politikon", no. 3.

Mendel M., 2017, Pedagogika miejsca wspólnego. Miasto i szkoła, Wydawnictwo Naukowe Katedra, Gdańsk.

Mendel M., Naumiuk A., Skrzypczak B., 2018, W trosce o społeczeństwo. Pedagogika społeczna w czasach nacjonalizmu, "Pedagogika Społeczna" no. 4(70), pp. 137-159.

Mendel M., Theiss W., 2019, Od redaktorów. Pamięć, miejsce i kategoria pamięciomiejsca w perspektywie społeczno-edukacyjnej, [in:] Pamięć i miejsce. Perspektywa społeczno-edukacyjna, Wydawnictwo UG, Gdańsk.

Pilch T., 1977, Szkoła i nauczyciel w procesie przemian środowiska wiejskiego, PWN, Warszawa.

Pilch T., 2001, Dzieci gorszych szans, KKWR, Warszawa.

Pilch T., 2008, Wyzwania pedagogiki społecznej na początku XXI wieku, "Pedagogika Społeczna", no. 4, pp. 9-32.

Pilch T., 2017, Nie możemy pozostać obojętni! A text distributed among the members of the Movement of Socially Engaged Pedagogues in the e-mail: Syryjskie dzieci (6.2.2017).

Pilch T., 2019, Miejsce, przestrzeń $i$ czas $w$ historii rodziny, [in:] Pamięć i miejsce. Perspektywa społeczno-edukacyjna, eds. Maria Mendel and Wiesław Theiss, Wydawnictwo Uniwersytetu Gdańskiego, Gdańsk.

Radlińska H., 1935, Stosunek wychowawcy do środowiska społecznego. Szkice z pedagogiki spoŁecznej, Nasza Księgarnia, Warszawa

Rosanvallon P., 2013, The Society of Equals, A. Goldhammer transl., Cambridge, MA \& London: Harvard University Press.

Skrzypczak B., 2016, Wspótczynnik społecznościowy. Edukacyjne (re)konstruowanie instytucji społecznościowych - w perspektywie pedagogiki społecznej, Akapit, Toruń.

Smolińska-Theiss B., 2018, Pedagogika społeczna - pedagogika społecznie zaangażowana. Wokót inicjatyw i ruchów społecznych, "Pedagogika Społeczna", no. 4(70). 
Theiss W., 2018a, Helena Radlińska: powrót do źródeł i tradycji w ponowoczesnym świecie, "Pedagogika Społeczna", no. 4(70).

Theiss W., 2018b, Demokratyczna szkoła polska. Niepodległościowy projekt Heleny Radlińskiej z lat 1906-1918, [in:] Pomorskie drogi do Niepodległej, eds. Józef Borzyszkowski and Cezary Obracht-Prondzyński, Gdańskie Towarzystwo Naukowe, Gdańsk.

\section{Internet sources}

Dąbrowska Z., 2016, A conversation with prof. Tadeusz Pilch. Nauczyciele wreszcie się obudzili, Rzeczpospolita, 24.06.2016, https://www.rp.pl/Edukacja/161029213-Rozmowa-z-profTadeuszem-Pilchem-Nauczyciele-wreszcie-sie-obudzili.html (access date: 11.06.2019).

Janicka A., Janiuk P., Kasprowicz M., Klimek W., Kubicka J., Kulaszewska P., Łupaczewska M., Witkowska E., Pilch T. (academic auspices), 2013, Dzieci na drogach Warmii i Mazur. Raport o dojazdach dzieci i młodzieży $w$ wybranych gminach województwa warmińsko-mazurskiego, cejsh.icm.edu.pl/cejsh/element/bwmeta1.element.../c/Kwartalnik2_2013_3. pdf (access date: 10.06.2019). 